\title{
KOCAELİ / BAŞİSKELE İLÇESİ AFET VE ACİL DURUM TOPLANMA ALANLARININ YETERLİKLERININ DEĞERLENDIRILIMESI
}

\author{
Serpil GERDAN ${ }^{*}$, Alper ŞEN ${ }^{2}$ \\ ${ }^{1}$ Kocaeli Üniversitesi, İzmit MYO, Kocaeli, Türkiye \\ ${ }^{2}$ Kocaeli AFAD İl Müdürlügü, Kocaeli, Türkiye
}

\begin{abstract}
Anahtar Kelimeler
AHP,

Afet Toplanma Alanı,

Afet Planlamasl,

Afet Risk Yönetimi,

Kriz Yönetimi.
\end{abstract}

\begin{abstract}
Öz
Doğal ya da insan kaynaklı tehlikelerin afete dönüşmemesi, koruyucu ve önleyici önlemlerin alınması ve risk azaltma faaliyetlerinin yürütülmesi ile mümkündür. Afetler sırası ve sonrasında kullanılmak üzere belirlenecek toplanma alanlarının kişi başına düșen alan açısından büyüklüğü, dağılım ve altyapı gibi özelliklerinin değerlendirilerek belirlenmesi afet yönetiminin en önemli konularından biridir. Bu çalışmada, Afet ve Acil Durum Yönetim Başkanlığı (AFAD) İl Müdürlükleri tarafından mahalle ve bölge düzeyinde belirlenen toplanma alanlarının yeterlikleri Kocaeli Başiskele ilçesi özelinde değerlendirilmiştir. Çalışmanın ilk aşamasında mevcut toplanma alanları uluslararası kriterlere bağlı olarak sınıflandırılmıș, ikinci aşamada ise bu alanların kriterlere göre uygunluk değerleri Analitik Hiyerarşi Prosesi (AHP) yöntemi ile belirlenmiștir. Çalıșmanın sonuçları Kocaeli ilinin Bașiskele ilçesi için belirlenen toplanma alanlarının \%77,14'ünün elektrik ve su altyapısına sahip olduğunu göstermektedir. Elde edilen veriler 22 mahallede belirlenmiş toplanma alanlarından sadece 5'inin metrekare açısından uygun olmadığını göstermektedir. Çalışmanın sonuçlarının afet planlama çalışmalarının verimliliğini arttırarak bölgenin afet risk yönetimi ve müdahale kapasitesinin geliştirilmesine katkı sağlayacağı umulmaktadır.
\end{abstract}

\section{EVALUATION OF QUALIFICATIONS OF DISASTER AND EMERGENCY ASSEMBLY POINTS FOR KOCAELİ BAŞISSKELE DISTRICT}

\begin{tabular}{l}
\hline Keywords \\
\hline AHP, \\
Disaster Assembly Point, \\
Disaster Planning, \\
Disaster Risk Management, \\
Crisis Management.
\end{tabular}

Crisis Management. \begin{abstract}
Natural and technological hazards do not turn into disasters by preventive and protective activities and risk reduction. One of the most important activities in disaster management is determining the size, distribution, and infrastructure of assembly points that should be taken into consideration to be used during and postdisaster. In this study, we examined the qualification of assembly points identified neighborhood and local level by the Provincial Directorates of Disaster and Emergency Management Presidency (AFAD) in the case of Kocaeli/Başiskele district. In the first phase of the study, the existing Assembly Points were classified according to international criteria, and in the second phase, the suitability values of these areas according to the criteria were determined by the Analytical Hierarchy Process (AHP) method. The results of this study show that 77,14\% of the assembly points designated for Başiskele have electricity and water infrastructure. According to data, it is found that only 5 of 22 neighborhood assembly points do not appear as proper assembly points in terms of square meters. We expect that our research outcomes should provide enhance the efficiency of planning studies, and contribute to the development of the region's capacity for disaster response and resilience.
\end{abstract}

Alıntı / Cite

Gerdan, S., Şen, A., (2020). Kocaeli/ Başiskele İlçesi Afet ve Acil Durum Toplanma Alanlarının Yeterliklerinin Değerlendirilmesi, Mühendislik Bilimleri ve Tasarım Dergisi, 8(2), 489-500. 


\begin{tabular}{l|l|l}
\hline Yazar Kimliği / Author ID (ORCID Number) & \multicolumn{3}{|l}{ Makale Süreci / Article Process } \\
\hline S. Gerdan, 0000-000 1-9126-7808 & Başvuru Tarihi / Submission Date & 03.02 .2020 \\
A. Şen, 0000-0002-8047-0330 & Revizyon Tarihi / Revision Date & 01.05 .2020 \\
& Kabul Tarihi / Accepted Date & 04.05 .2020 \\
& Yayım Tarihi / Published Date & 25.06 .2020 \\
\hline
\end{tabular}

\section{Giriş (Introduction)}

İnsanlığın başlangıcıyla birlikte bireysel yaşamdan toplumsal yaşama geçiş başlamıştır. Toplulukların oluşmasını takiben yaşam alanlarını ve çevreyi olumsuz etkileyecek doğadan veya insandan kaynaklı tehlikeler ve tehditler meydana gelmiş ve toplumsal faaliyetler kesintiye uğramıștır. Günümüzde, normal yaşamı ve insan faaliyetlerini durdurarak veya kesintiye uğratarak toplulukları etkileyen doğal, teknolojik veya insan kökenli tehlikelerin yerel imkanlarla baş edilemeyecek boyuta ulaşması afet olarak tanımlanmaktadır (Kadıoğlu, 2008). Aslında bu tanımın vurgusu olayın kendisinden çok, ortaya çıkan sonuçların afet olarak nitelendirilmesidir (Gerdan ve Şen, 2019). Birleşmiş Milletler Uluslararası Doğal Kaynaklı Afet Azaltılması On Yılı Sekretaryası (IDNDR: International Decade for Natural Disaster Reduction), tehlikelerden kaynaklanan risklerin olumsuz etkilerinin giderilmesi için bireyden topluma her kesimin sorumluluğunun olduğuna vurgu yapmaktadır (Güvel, 2001). Ayrıca, Sendai Afet Risk Azaltma Çerçevesi Eylem Planında (2015-2030) tehlikelerden kaynaklanan risklerin olumsuz etkilerinin giderilmesi için bireyden topluma her kesimin sadece sorumluluğunun değil katılımının da gerekli olduğuna vurgu yapılmaktadır. İnsanlar tarafından korkutucu ve afet ya da felaket olarak nitelendirilen deprem, firtına, sel veya volkanik patlamalar gibi doğadan kaynaklı olaylar, yeryüzünün fiziki özelliklerinin oluşumunun birer parçasıdır. Her yıl çeşitli sıklık ve büyüklükte meydana gelen doğa olaylarının sonucunda yaşanan can ve mal kayıpları aslında insanoğlunun yaşadığı çevreyi iyi algılayamamasının bir sonucudur ve risk teşkil eden bölgelerde planlamadan yoksun yerleşim alanlarının kurulması insan hayatına mal olabilmektedir (Birand ve Ergünay, 2001; Demirci ve Karakuyu, 2014; Gerdan ve Şen, 2019). Gelişen teknoloji ve yönetim anlayışı, afetlerle mücadelenin sadece afet anında hızlı ve etkili müdahale ile sınırlı olmadığını açıkça göstermektedir. Ülkeler üzerinde farklı etkilere sahip olabilme potansiyellerinden dolayı afetlerle mücadele hem zordur hem de tek bir doğru model yoktur. Bu nedenle, bilimsel ve teknolojik gelişmelerin kullanıldığı, eğitim, hazırlık faaliyetlerini ve yönetimi de kapsayan modellerin geliştirmesi gerekir (Press ve Hamilton, 1999).

Türkiye, gerek meteorolojik gerekse jeolojik ve topografik koşullara bağlı olarak sıklıkla afetlere maruz kalmaktadır. Ekonomik durum ve nüfus yoğunluğu gibi bölgesel şartlara bağlı olarak bu kayıplar gün geçtikçe artan bir eğilim göstermektedir (Erkan vd., 2018). İçişleri Bakanlığı Afet ve Acil Durum Yönetim Başkanlığı (AFAD)'ın Doğal Kaynaklı Afet İstatistiği Raporuna göre ülkemizde 1900-2018 yılları arasında 210 yıkıcı deprem (en az 6 büyüklüğünde), 6334 sel/su baskını, 23041 heyelan ve 1539 çı̆̆ meydana gelmiştir. Bu afetlerden sadece deprem kaynaklı can kaybı sayısı 86000'in üzerindedir (AFAD, 2019). Bu durum ülkemiz coğrafyasını tehdit eden tehlikeler dikkate alınarak bölgesel risk azaltma çalışmalarının yürütülmesini kaçınılmaz kılmaktadır.

Afet ve acil durum yönetimi geçmiş deneyimlerle geliştirilen ve süreklilik gerektiren bir yönetim şeklidir. Kriz anında sürdürülebilir bir anlayışın benimsenmesi ve krizin en hafif hasarla atlatılabilmesi için sorumlu kurumlar arasında işbirliği ve koordinasyonu gerekir. Başarılı bir afet ve acil durum yönetim sistemi; afet öncesi, sırası ve sonrası aşamaları sistem içerisinde barındıran, tüm paydaşların sisteme dahil edildiği ve tüm etkilerin ön görülebildiği modellerin geliştirilebilmesi ile mümkün olabilir. İnsanlara sosyal ve kültürel avantajlar sunulmasına bağlı olarak kentsel alana artan ilgi toplumu maalesef tehlikelere karşı daha kırılgan hale getirmektedir. Bunların sonucu olarak kentler fiziksel, ekonomik ve sosyal kayıpların en ağır biçimde gerçekleştiği alanlar olmakta, tehlike kaynaklı riskler değișirken, kentte yaşayan nüfus başta olmak üzere diğer zarar görebilirlikler de artmaktadır (Da Silva ve Morera, 2014).

Bu bağlamda, araştırmamıza konu olan, Kocaeli Yarımadasının temel kayaları Palezoyik yaşlı kalın bir çökel istif ile temsil edilmektedir. Bölge Kuzey Anadolu Fayı ve onun kolları ile gelişmiş sağ yanal atımlı faylarla karakterize edilmesi nedeniyle de aktif fay kuşağı üzerinde yer almaktadır (Çuvaş, 2002). Yüzölçümü 3.623 km² olan Kocaeli ili $29^{\circ} 22^{\prime}-30^{\circ} 21^{\prime} \mathrm{E}, 40^{\circ} 31^{\prime}-41^{\circ} 13^{\prime} \mathrm{N}$ coğrafi koordinatlarında olup kuzeyinde Karadeniz, doğusunda Sakarya, güneyinde Bursa ve batısında İstanbul ile Yalova illeri bulunmaktadır. 2019 nüfusu, tahmini verilere göre 1.946.252 ve kilometre kareye düşen kiși sayısı da 526 dır. 1900-2016 yılları arasında aletsel büyüklüğü 2 den büyük ve 7,4 den küçük toplam 5.301 deprem meydana gelmiștir (Akyürek ve Arslan, 2018).

Bu çalışma ile Kocaeli ili Başiskele ilçesinde Kocaeli AFAD İl Müdürlüğü tarafından mahalle/bölge ölçeğinde belirlenmiş 35 adet toplanma alanının konum, nitelik ve ortaya çıkacak ihtiyaçları karşılayabilme kapasiteleri açısından yeterlilik düzeyleri değerlendirilmiştir. Yüzölçümü $215 \mathrm{~km}^{2}$ olan ilçede, km² ye yaklaşık 293 kişi düşmektedir. İlçenin kuzeyi İzmit Körfezi ve İzmit ilçesi, güneyi Bursa ve Sakarya ili, doğusu Kartepe ilçesi ve batısı 
Gölcük ilçesi ve Bursa ili ile çevrilidir. Zengin su kaynaklarına sahip olan ilçede Yuvacık barajı yer almaktadır. 2018 yılı nüfus verilerine göre ilçenin toplam nüfusu 97.817 dir (URL-6).

\section{Afet ve Acil Durum Toplanma Alanlarının Standartları (Standards of Disaster and Emergency Assembly Points)}

Genel olarak afet ve acil durumlar için belirlenen toplanma alanları, olağan durumlarda yeşil alan veya park olarak kullanılan ancak afet anı ve tahliye sonrasında acilen ulaşılabilecek, güvenli bölge olarak nitelendirilen alanlardır (Gerdan ve Şen, 2019). Bu nedenle gerek fiziksel, yapısal, altyapı, ulaşım gerekse doğal yapı, jeolojik ve coğrafi olarak risk oluşturmayacak yerleșime uygun alanlardan seçilmeli ve insani temel ihtiyaçları karşılayabilecek donanıma sahip olmalıdır (Maral vd., 2015). Afete maruz bireylerin bilgilendirilmesi başta olmak üzere acil yardım ekipleri ile koordinasyon ve geçici barınma gibi birçok afet öncesi risk yönetimi planlama ve tahliye tatbikatları, afet sırası ve sonrası kriz yönetimi ve lojistik faaliyetleri yine toplanma alanları tasarım çalışmaları üzerinden yürütülmektedir (JICA, 2002; Aksoy vd., 2009; Çınar vd., 2018).

$\mathrm{Bu}$ alanların kapasite ve mekânsal dağılımlarının afet sırası ve sonrası için orta ve uzun vadeli birçok faaliyete katkı sağlayacağı unutulmamalıdır (Erdin vd., 2017). Kısa vadede toplanma ve temel ihtiyaçların karşılanması, orta ve uzun vade de ulaşım ve lojistik hizmetlerin yürütülmesi bu alanlar için kritik görevlere örnek olarak verilebilir. $\mathrm{Bu}$ nedenle mevcut belirlenmiș toplanma alanlarının durumlarının değerlendirilmesi veya üstlenecekleri görevlere bağlı olarak yeni toplanma alanlarının belirlenmesinde kapasite, yer seçimi, mekânsal dağılım, koordinasyon ve lojistik hizmetlerinin nasıl sağlanacağının iyi değerlendirilmesi gerekir (Erden ve Coşkun, 2010; Çavuş, 2013; Kırçın vd., 2017). Bu alanların afet sonrası hizmetlerin yürütülmesi açısından adapte olabilir nitelikte olması da bir diğer önemli konudur. Park, bahçe ve rekreasyon alanı olarak tanımlanan açık yeşil alanlar, meydan, yol gibi kamusal veya özel mülkler ve tüm açık alanların deprem başta olmak üzere afetler sonrası afetzedeler için kısa ve uzun vadede sığınma ve barınma ihtiyaçlarının karşılanacağı mekanlar haline dönüştürülebilir nitelikte olması gerekir (Gül ve Küçük, 2001; Çelik vd., 2018; Yalçıner Çal ve Aydemir, 2018; Gerdan ve Şen, 2019).

Toplanma alanlarının belirlenmesine yönelik kriterler ile yer seçimine dair standartlar ulusal ve uluslararası birçok çalışmada belirtilmiştir. Yer seçimi kriterleri Çınar ve diğ. (2018) ve JICA, (2002)'ye göre 5 ana başlık altında toplanmıştır (Çınar vd., 2018; URL-1; URL-2, JICA, 2002).

1. Uzaklık ve erișilebilirlik: Yapı alanlarına olan uzaklık göz önünde bulundurulmalı, 0-500 m yürüyüș mesafesinde, tahliye alanının sınırına yakın ve herkes tarafından erişilebilir olmalıdır.

2. Ana yol bağlantıları: Ana yollarla bağlantılı alanlar ve riskli yollara ait alternatifler değerlendirilmelidir.

3. Çok fonksiyonluluk ve kullanış: Mevcut yeşil alanlar, çocuk oyun alanları ile parklar, okul veya cami gibi kapalı alanlar değerlendirilmelidir.

4. Kamu arazileri: Kamuya ait araziler öncelikli alanlar olarak değerlendirilmeli, yapısal olarak güvenli olup olmadıkları dikkate alınmalıdır.

5. Büyüklük: JICA, (2002)'ya göre kişi başına minimum 1,5 m², Tarabanis ve Tsionas (1999)'a göre ise 2 m² olarak kabul edilmektedir (JICA 2002; Tarabanis ve Tsionas, 1999).

\section{Materyal ve Yöntem (Material and Method)}

\subsection{Kocaeli İl Afet Müdahale Planı ve Toplanma Alanları (Kocaeli Provincial Disaster Response Plan and Assembly Points)}

Toplanma alanlarının Türkiye'deki durumuna yönelik en önemli strateji Türkiye Afet Müdahale Planı (TAMP) bünyesinde geliştirilmiştir. TAMP içinde afet öncesi, sırası ve sonrası için acil durum toplanma alanlarının belirlenmesi, uygunluğunun kontrol edilmesi, tahliye öncelikleri, tahliye yolları ve tahliye edilecek bölgelerin saptanması, planlama ve uygulama süreçleri ile ilgili detaylı bilgiler yer almaktadır. (URL-3). Türkiye genelinde TAMP, 2014 yılında yayımlanmış; 2015 yılı bașında ulusal düzey hizmet grubu planları hizmete alınmıştır. Ayrıca, Mekânsal Planlar Yapım Yönetmeliğinin 24. Maddesi 10-p bendinde de toplanma alanları ile ilgili kurum ve kuruluşlardan verilerin elde edilmesi ve analizi ile ilgili hükümlere yer verilmiştir (URL-4). Afetlere yönelik il düzeyindeki faaliyetler Afet ve Acil Durum İl Müdürlükleri tarafindan yürütülmektedir. 15 Temmuz 2018 tarihinde yayınlanan 4 No’lu Cumhurbaşkanlığı Kararnamesi ile Afet ve Acil Durum Yönetimi Başkanlığı İçişleri Bakanlığına bağlanmıștır. TAMP kapsamında 2015 yılında Kocaeli AFAD İl Müdürlüğü tarafından Kocaeli Afet Müdahale Planı (KAMP) hazırlanmıştır. Plan, afet ve acil durum yönetimi konusunda yetkili kurumlar ile bunların iş tanımları ve görevlendirmeleri ile tüm ilçeler için Afet Toplanma Alanlarına ait verileri içermektedir. 27 Eylül 2018 tarih ve 328500907-952.01.03 sayılı talimat ile Kocaeli ili sınırlarında belirlenmiș afet ve acil durum toplanma alanlarının belirlenmesinde nüfus yoğunluğu, ulaşılabilirlik ve tahliye kolaylığı, engelli ve yaşlıların erişebilirliğinin 
uygunluğu, yangın, heyelan, su taşkını, tsunami ve benzeri gibi ikincil tehlikeler ile deniz, akarsu kenarları, sıvılaşma olabilecek alanlar, fay hatlarına yakınlık, engebesiz düz arazilerin seçilmesi, elektrik, su, tuvalet gibi temel ihtiyaçların ve benzeri unsurların dikkate alınarak mümkün olduğunca kamuya ait uygun alanların mekansal verilerinin belirlenmesi ve/veya daha önce belirlenmiş verilerin güncellenmesinin sağlanması çalışmaları başlatılmıştır (Gerdan ve Şen, 2019).

\subsection{Başiskele İlçesi Toplanma Alanları (Başiskele District Assembly Points)}

Kocaeli ili, 1999 depreminde acı kayıplar yaşamış olup tektonik açıdan aktif bir bölgede yer almaktadır. Başiskele ilçesi, 1999 yılında Gölcük merkezli yaşanan depremin yaşandığı ilçe olması sebebiyle Kocaeli ilinin deprem açısında en kırılgan ilçelerinden biridir. Bu nedenle ilçe sınırları içerisinde belirlenecek toplanma alanları afetlere dirençlilik açısından oldukça önemli bir konu olarak dikkat çekmektedir. Başiskele ilçesi için 22 mahallede afetzedelerin toplanacağı 35 adet açık alan toplanma alanı belirlenmiştir ve bu alanların tamamına yakını park, spor tesisi ve okullardan seçilmiştir (URL-5: TAMP Kocaeli, 2018).

Bu çalışmada, Başiskele ilçesi için belirlenmiş toplanma alanlarının yeterlikleri uluslararası kriterler ve aşağıda özetlenmiş bileşenlere bağlı olarak değerlendirilmiştir.

(i) Toplanma alanı olarak kullanılabilecek kentsel alanların dağılımı, büyüklükleri, sunduğu olanaklar, dağılımları ve birbiri ile bağlantıları,

(ii) Stratejik noktalar ve toplanma alanlarını birbiri ile bağlayan kaçış ve bağlantı yollarının durumunun uygunluğu, alternatifli olup olmadı̆̆ı.

Kocaeli TAMP kapsamında Körfez ilçesinde petrokimya tesislerinin ve Başiskele ilçesinde Yuvacık Barajının olası ikincil afet riski taşıması nedeniyle bu iki 2 ilçe için belirlenen alanlar aynı zamanda stratejik tahliye alanları olarak da ifade edilmektedir. AFAD il müdürlüğü kişi başına düşen boş alan açısından toplanma alanlarına yönelik kriteri ilçe bazında $2 \mathrm{~m}^{2}$ olarak planlamış ve alan belirleme çalışmalarına bu doğrultuda başlanmıştır. 2015 yılında gerçekleştirilen toplanma alanları yer seçimi sürecinde her ne kadar mevcut toplanma alanlarının belirlenmesinde tehlike ve tehditlere karşı korunabilen, kontrol merkezlerine yakın mesafede, genişlemeye uygun alanlar tercih edilmiş olsa da maalesef zemin açısından değerlendirme bir ön koşul olarak kullanılmamıștır.

\section{Araştırma Bulguları (Research Findings)}

Afet anında kişilerin toplanması için uygun alanların belirlenmesi, bireylerin hızlı ve etkin bir şekilde organize olabilmeleri, müdahale, hasar tespit ve insani yardım ihtiyaçlarının daha hızlı karşılanabilmesi, eksik veya kayıp kişilerin tespiti ve gerekli arama kurtarma çalışmalarının yönlendirilmesi oldukça önemlidir (Çiçekdağı ve Kırış, 2012). Başiskele ilçesi sınırlarında ilgili talimatla 2019 yılında son güncellemeleri yapılan afet ve acil durum toplanma alanlarına ait bilgiler çalışma içerisinde belirlenen kriterler ve bileşenler doğrultusunda Ek-1'de listelenmiș olup afet ve acil durum toplanma alanlarının mekansal dağılımları Şekil 1'de gösterilmiştir.

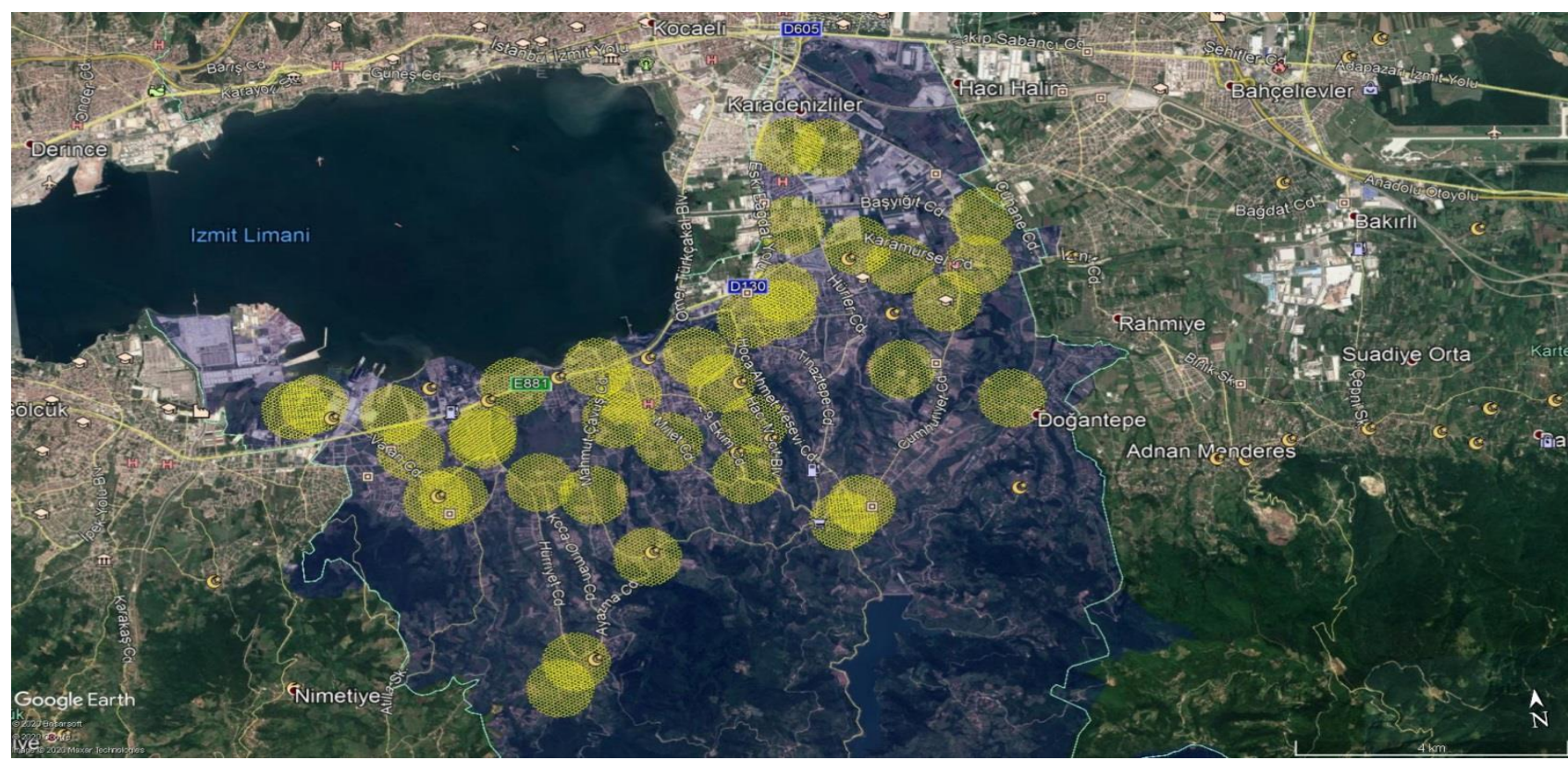

Şekil 1: Başiskele İlçesi Toplanma Alanlarının Mekansal Dağılımı (500 m yarıçapta-yaklaşık 5 dk yürüme mesafesi) (çizgi ölçeği 4 km/birim dir) (Spatial Distribution of Basiskele District Assembly points- $500 \mathrm{~m}$ radius, 5 min. walking distance) 
Ek-1 verilerine göre Başiskele ilçesi toplanma alanlarının ulaşım, altyapı ve kişi başı alan açısından uygunluk dağılımı Tablo 1'de özetlenmiştir.

Tablo 1. Başiskele İlçesi Toplanma Alanları Uygunluk Dağılımı (Distribution of relevance to Başiskele District Assembly points)

\begin{tabular}{|c|c|c|c|c|c|}
\hline & & \multicolumn{2}{|c|}{ Uygun Toplanma Alanı } & \multicolumn{2}{|c|}{$\begin{array}{c}\text { Uygun Olmayan Toplanma } \\
\text { Alanı }\end{array}$} \\
\hline & & f & $\%$ & f & $\%$ \\
\hline \multirow{5}{*}{ 离 } & Ana caddeye cephe & 24 & 68,57 & 11 & 31,43 \\
\hline & Denize uzaklık $(>200 \mathrm{~m})$ & 32 & 91,43 & 3 & 8,57 \\
\hline & Yüksek yapılardan uzaklık (>30 m) & 25 & 71,43 & 10 & 28,57 \\
\hline & Yaya yolu & 32 & 91,43 & 3 & 8,57 \\
\hline & Engelli yolu & 27 & 77,14 & 8 & 22,86 \\
\hline \multirow{3}{*}{ 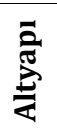 } & Elektrik & 27 & 77,14 & 8 & 22,86 \\
\hline & $\mathrm{Su}$ & 27 & 77,14 & 8 & 22,86 \\
\hline & WC & 26 & 74,29 & 9 & 25,71 \\
\hline \multirow{4}{*}{ 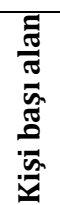 } & $0-0,99 \mathrm{~m}^{2}$ & & & $2^{*}$ & 5,71 \\
\hline & $1-1,99 \mathrm{~m}^{2}$ & & & $3^{*}$ & 8,57 \\
\hline & $2-2,49 \mathrm{~m}^{2}$ & & & $3^{*}$ & 8,57 \\
\hline & $2,5 \mathrm{~m}^{2}$ büyük & $14^{*}$ & $63,63 \%$ & & \\
\hline
\end{tabular}

*Kişi başı alan mahalle bazında hesaplanmıştır.

Başiskele ilçesi için AFAD İl Müdürlüğü tarafından afet ve acil durumlarda kullanılmak üzere belirlenen 35 adet toplanma alanının \%68,57'si ( $\mathrm{f}=24$ ) ana caddeye cephe, \% 91,43'ü ( $\mathrm{f}=32$ ) denize 200 m'den daha uzak, \%71,43'ü ( $\mathrm{f}=25$ ) yüksek yapılardan 30 m'den daha uzak konumda yer almaktadır. Toplanma alanlarının \%91,43'ü (f=32) yaya yoluna sahip, \%77,14'ü ( $\mathrm{f}=27$ ) ise engelli (özel gereksinimli bireylerin erişilebilirliği) yoluna sahiptir. 35 toplanma alanının 27 tanesi $(\% 77,14)$ elektrik ve su altyapısına sahipken, 26 tanesinde $(\% 74,29)$ WC mevcuttur. Fatih Mahallesinde bulunan Yuvacık İlk ve Ortaokulu toplanma alanı 0,25 $\mathrm{m}^{2}$ ile kişi başına düşen alan açısından en uygunsuz alan iken, Ovacık Mahallesi-Kullar açık spor tesisi toplanma alanı $25 \mathrm{~m}^{2}$ ile kişi başına düşen alan açısından en uygun alan olarak görünmektedir.

\section{5. Çok Kriterli Karar Verme Yöntemi ile Toplanma Alanlarının Değerlendirilmesi (Evaluation of Assembly Points by Multi-Criteria Decision Making Method)}

Çok kriterli karar verme yöntemleri seçme, sıralama ve sınıflandırma olmak üzere üç ana bașlık içermektedir. Günümüzde bu alanda çok sayıda yöntem ve teknik kullanılmakta olup bunlara, AHP, TOPSIS, ANP, VIKOR, ELECTRE, MACHBETH, MAUT/UTA gibi yöntemler örnek olarak verilebilir (Çelikbilek, 2018). Çok kriterli karar verme tekniklerinde zaman içerisinde yaşanan gelişim ve çeşitlilik, karar verme aşamasında hangi seçeneğin tercih edilmesi gerektiği hususunu ortaya çıkarmaktadır. İdeal yönteme ilişkin bir kural bulunmamakla birlikte problemin niteliği ile yöntemin uyumunun dikkate alınması önemlidir. Bu çalışma için belirlenen karar verme yöntemi Analitik Hiyerarşi Prosesi (AHP) olarak belirlenmiştir.

\subsection{Analitik Hiyerarşi Prosesi (AHP) Yöntemi (Analytical Hierarchy Process Method)}

AHP, 1980 yılında Thomas L. Saaty tarafından geliştirilen, yaygın olarak seçme veya sıralama problemleri için kullanılan bir yöntemdir (Saaty, 1980). Bu yöntem karar verme problemlerinin çözümünde sadelik, kolay anlaşılabilirlik ve rahat kullanılabilirlik amacıyla geliştirilmiştir (Aktaş vd., 2015). AHP yönteminin özü, kriterler ile alternatifler arası ikili karşılaştırma esasına dayanmaktadır. Tüm kriterler arasında önem seviyelerinin belirlenmesi karar vericinin görüşlerine dayanmaktadır. Problemin tanımlanması ile başlayıp nihai önceliğin belirlenmesi ile biten AHP akıș şeması Şekil 2'de şematik olarak verilmiştir. Karar vericiler tarafından kriterlerin değerlendirilmesinde Saaty tarafından geliştirilen 1-9 ölçeği kullanılarak kriterler arasında bir öncelik sırası oluşturulur (Yıldırım ve Önder, 2018). 


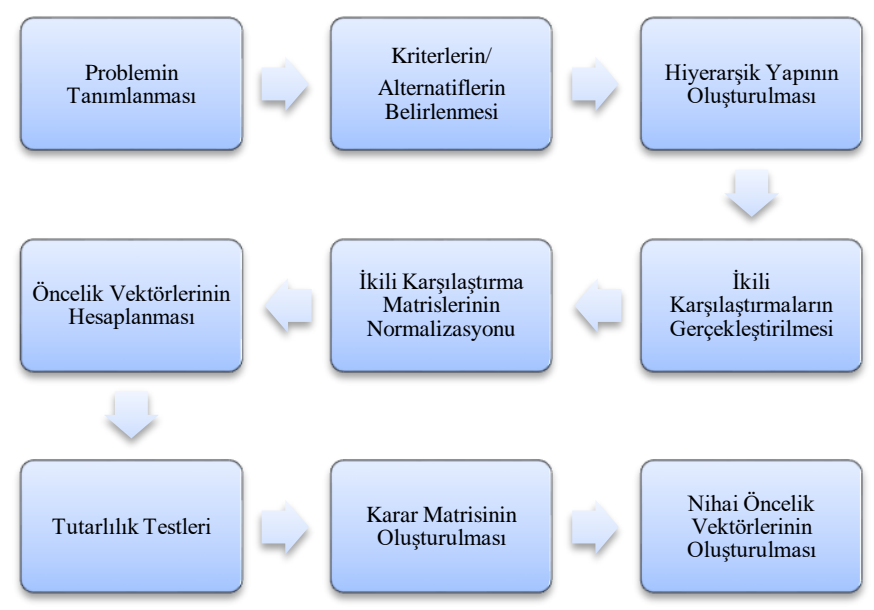

Şekil 2. AHP Akış Şeması (Çelikbilek, 2018) (Analytical Hierarchy Process -AHP- flow chart)

Kriterler ve alternatifler arasında karar vericiler tarafından yapılan önem sıralaması ve karşılaştırmada kullanılan Saaty'nin 1-9 ölçeği Tablo 2'de, Saaty ölçeğini kullanılarak kriterler arasında yapılan göreli puanlama matrisi ise Tablo 3'de verilmiștir (Saaty, 1990).

Tablo 2. AHP İkili Karşılaștırma Ölçeği (Saaty, 1990) (AHP Binary Comparison Scale)

\begin{tabular}{|ll|}
\hline Sayısal Değer & Önem Derecesi \\
\hline 1 & Eşit derecede önemli \\
3 & Biraz önemli \\
5 & Önemli \\
7 & Çok Önemli \\
9 & Son derece önemli \\
$2,4,6,8$ & Ara değerler \\
\hline
\end{tabular}

Tablo 3. AHP İkili Karşılaştırma Matrisi (AHP Binary Comparison Matrix)

\begin{tabular}{|c|c|c|c|c|c|}
\hline Kriterler & 1 & 2 & 3 & $\ldots$ & $n$ \\
\hline 1 & $w_{1} / w_{1}$ & $w_{1} / w_{2}$ & $w_{1} / w_{3}$ & $\ldots$ & $W_{1} / W_{n}$ \\
\hline 2 & $w_{2} / w_{1}$ & $w_{2} / W_{2}$ & $w_{2} / w_{3}$ & $\ldots$ & $W_{2} / W_{n}$ \\
\hline 3 & $w_{3} / w_{1}$ & $w_{3 / w_{2}}$ & $w_{3} / w_{3}$ & $\ldots$ & $W_{3} / W_{n}$ \\
\hline$\ldots$ & $\ldots$ & $\ldots$ & $\ldots$ & $\ldots$ & $\ldots$ \\
\hline$n$ & $W_{n} / W_{1}$ & $W_{n} / W_{2}$ & $W_{n} / W_{3}$ & $\ldots$ & $W_{n} / W_{n}$ \\
\hline
\end{tabular}

Matrisin köşegen değerlerinin her biri kriterin kendi puanına bölünmesiyle köşegen 1 değerini alır. W2/W1 değeri ikinci kriterin birinci kriter ile karşılaştırılmasını ifade etmektedir. Bu oran iki numaralı kriterin bir numaralı kritere göre ne derece önemli olduğunu gösterir (Şahin ve Akyer, 2011; Hazırcı ve Şahin, 2019). İkili karşılaştırmalar matrisinin elde edilmesinin ardından $\left(\mathrm{a}_{\mathrm{ij}}\right)$, ölçütlerin birbirine göreceli değerleri sütun toplamına bölünerek ölçütlerin normalize edilmiş değerleri belirlenir. Normalize edilmiş ikili karşllaştırma matrisi denklem 2.1 yardımı ile elde edilir (Saaty, 1994).

$$
b_{i j}=\frac{a_{i j}}{\sum_{i=1}^{n} a_{i j}}
$$

Normalizasyon adımından sonra, normalize edilmiş ikili karşılaştırma matrisinin satır ortalamaları alınarak öncelik vektörü bulunur. Öncelik vektörü (önem değeri) için denklem 2.2 kullanılmaktadır. Burada, $c_{i j}=i$. öğenin j. öğeye göre önem değerini ifade etmektedir.

$$
w_{i}=\frac{\sum_{j=1}^{n} c_{i j}}{n}
$$

\subsection{Başiskele İlçesi İçin Kriterlerin Belirlenmesi ve Öncelik Vektörü (Determination of Criteria and Priority Vector for Başiskele District)}

AHP yönteminin temelinde her bir kriter için alternatiflerin değerlendirilerek karar vericiler açısından en uygun ve doğru sonucun elde edilmesi yatmaktadır. Bu nedenle normal şartlarda afet ve acil durumlarda kullanılmak 
üzere belirlenecek toplanma alanları için mevcut alternatiflerin kriterlere bağlı olarak değerlendirilmesi gerekir. Ancak il veya bölgenin plansız ve hızlı kentleşmesi, nüfus yoğunluğunun planlamadan bağımsız artışı gibi sebeplere bağlı olarak bunu gerçekleştirmek çoğu zaman mümkün olmamaktadır. Çalışmanın bu bölümünde Bașiskele ilçesi için afet ve acil durumlarda kullanılmak üzere belirlenmiş toplanma alanlarının değerlendirilmesi AHP yöntemi kullanılarak gerçekleştirilmiştir. Kriterler ve bu kriterlere bağlı alt kriterlerin hiyerarşisi oluşturulmuş ve kriterlerin öncelik vektörü hesaplanmıştır. Afet ve acil durum toplanma alanları için değerlendirme kriterleri bilimsel yazın araştırması, uluslararası standartlar ve AFAD Kocaeli İl Müdürlüğünde görevli personellerin görüşleri doğrultusunda belirlenmiştir. Ana kriterler ulaşılabilirlik (A1), altyapı (A2) ve kapasite (A3) olmak üzere 3 başlık altında toplanmıștır. Belirlenen A1 ana kriteri 5 ve A2 ana kriteri 3 adet alt kritere sahiptir. Ana ve alt kriterler Tablo 4' de verilmiştir.

Tablo 4. Ana ve Alt Kriterler (Main and Sub Criteria)

\begin{tabular}{|c|c|c|}
\hline Ana Kriter & $\begin{array}{l}\text { Alt Kriter } \\
\text { Numarası }\end{array}$ & Alt Kriterler \\
\hline \multirow{5}{*}{ Ulaşılabilirlik (A1) } & U1 & Ana caddeye cephe \\
\hline & $\mathrm{U} 2$ & Denize uzaklık $(>200 \mathrm{~m})$ \\
\hline & $\mathrm{U} 3$ & $\begin{array}{l}\text { Yüksek yapılardan uzaklık (>30 } \\
\text { m) }\end{array}$ \\
\hline & $\mathrm{U} 4$ & Yaya yolu \\
\hline & U5 & Engelli yolu \\
\hline \multirow[t]{3}{*}{ Altyapı (A2) } & AY1 & Elektrik \\
\hline & AY2 & $\mathrm{Su}$ \\
\hline & AY3 & WC \\
\hline Kapasite (A3) & & $\begin{array}{l}2 \mathrm{~m}^{2} \text { den büyük kişi başı boş } \\
\text { alan }\end{array}$ \\
\hline
\end{tabular}

Belirlenen kriterlerin ağırlıklandırılması için bir form hazırlanmış ve Kocaeli AFAD İl Müdürlüğünde görevli, alanında deneyimli uzmanlar ile 2019 Aralık ayı içerisinde belirli dönemlerde görüșmeler yapılmıștır. Ana kriterler için ikili karşılaştırma ile normalizasyon ve öncelik vektör tablosu Tablo 5 ve Tablo 6' da, alt kriterler için ikili karşılaştırma ile normalizasyon ve öncelik vektör tabloları sırasıyla Tablo 7, 8, 9 ve 10'da verilmiştir.

Tablo 5. Ana Kriterler İkili Karșılaștırma Matrisi (Main Criteria Binary Comparison Matrix)

\begin{tabular}{|l|c|c|c|}
\hline Ana Kiriterler & A1 & A2 & A3 \\
\hline A1 & 1 & 1,527524 & 0,845154 \\
\hline A2 & 0,654653 & 1 & 0,333333 \\
\hline A3 & 0,632456 & 3 & 1 \\
\hline
\end{tabular}

Tablo 6. Normalizasyon ve Öncelik Vektörünün Belirlenmesi (Determination of Normalization and Priority Vector)

\begin{tabular}{|l|c|c|c|l|}
\hline Ana Kriterler & A1 & A2 & A3 & Öncelik Vektörü (W) \\
\hline A1 & 0,43723 & 0,27634 & 0,38795 & 0,3671 \\
\hline A2 & 0,28623 & 0,18091 & 0,15301 & 0,2067 \\
\hline A3 & 0,27653 & 0,54273 & 0,45903 & 0,4261 \\
\hline
\end{tabular}

Tablo 7. Ulașım Alt Kriterleri İkili Karşılaștırma Matrisi (Transportation Sub-Criteria Binary Comparison)

\begin{tabular}{|c|c|c|c|c|c|}
\hline Kriterler & U1 & U2 & U3 & U4 & U5 \\
\hline U1 & 1 & 0,6546 & 0,1259 & 1 & 0,8164 \\
\hline U2 & 1,5275 & 1 & 0,5773 & 2,2360 & 3,8729 \\
\hline U3 & 7,9372 & 1,7320 & 1 & 5 & 5,916 \\
\hline U4 & 1 & 0,4472 & 0,2 & 1 & 3 \\
\hline U5 & 1,2247 & 0,2581 & 0,1690 & 0,3333 & 1 \\
\hline
\end{tabular}

Tablo 8. Ulaşım Alt Kriterleri İçin Normalizasyon ve Öncelik Vektörünün Belirlenmesi (Determination of Normalization and Priority Vector for Transportation Sub-Criteria)

\begin{tabular}{|c|c|c|c|c|c|c|}
\hline Kriterler & U1 & U2 & U3 & U4 & U5 & Öncelik Vektörü (W) \\
\hline U1 & 0,078 & 0,159 & 0,060 & 0,104 & 0,055 & 0,099 \\
\hline U2 & 0,120 & 0,244 & 0,278 & 0,233 & 0,265 & 0,214 \\
\hline U3 & 0,625 & 0,423 & 0,482 & 0,522 & 0,405 & 0,510 \\
\hline U4 & 0,078 & 0,109 & 0,096 & 0,104 & 0,205 & 0,094 \\
\hline U5 & 0,096 & 0,063 & 0,081 & 0,034 & 0,068 & 0,080 \\
\hline
\end{tabular}


Tablo 9. Altyapı Alt Kriterleri İkili Karşılaştırma Matrisi (Infrastructure Sub-Criteria Binary Comparison Matrix)

\begin{tabular}{|c|c|c|c|}
\hline Kriterler & AY1 & AY2 & AY3 \\
\hline AY1 & 1 & 0,258199 & 0,333333 \\
\hline AY2 & 3,872983 & 1 & 1,732051 \\
\hline AY3 & 3 & 0,57735 & 1 \\
\hline
\end{tabular}

Tablo 10. Altyapı Alt Kriterleri İçin Normalizasyon ve Öncelik Vektörünün Belirlenmesi (Determination of Normalization and Priority Vector for Infrastructure Sub-Criteria)

\begin{tabular}{|c|c|c|c|c|}
\hline Kriterler & AY1 & AY2 & AY3 & Öncelik Vektörü (W) \\
\hline AY1 & 0,12701 & 0,14066 & 0,10874 & 0,12547 \\
\hline AY2 & 0,49193 & 0,54479 & 0,56503 & 0,53392 \\
\hline AY3 & 0,38105 & 0,31453 & 0,32622 & 0,34060 \\
\hline
\end{tabular}

Tamamlanmış ikili karşılaştırmaların, kendi içerisinde tutarlı olup olmadığının tespit edilmesi gerekir. Tutarlılık testlerini gerçekleştirebilmek için;

- Uyum İndeksi (CI; consistency index)

- $\quad$ Rastgele İndeks (RI; Random Consistency Index)

- Uyum Oranı (CR)

değerlerine ihtiyaç duyulmaktadır.

$\mathrm{CR}=\frac{\mathrm{CI}}{\mathrm{RI}}$ formülü tutarlılık oranının hesaplanması için kullanılır. Tutarlılık indeksinin (CI) rassal tutarlılık indekse (RI) bölünmesiyle elde edilen oranın 0,1 değerinden küçük olması karşılaştırmanın tutarlı olduğunu gösterir. Hesaplamalarda kullanılacak olan rastgele indeks (RI) değeri, kriter sayısına göre değişen ve Thomas Saaty tarafından rastsal üretilen karşılıklı kıyaslama matrisinin büyük örnekleminden geliştirilmiş olan değerlerdir (Yıldırım ve Önder, 2018). CR değerinin bulunabilmesi için uyum indeksi (CI) ve rastgele indeks (RI) değerlerinin belirlenmesi gerekmektedir. n kriter sayısı olmak üzere, Uyum indeksi denklem 2.3 eşitliği yardımı ile hesaplanmaktadir.

$$
\mathrm{CI}=\frac{\lambda-\mathrm{n}}{\mathrm{n}-1}
$$

$\lambda$ (Lamda) değerini bulmak için, öncelikle normalize edilmemiş haliyle a karşılaştırma matrisi ile w öncelik vektörünün matris çarpımından aşağıdaki d sütun vektörü elde edilir (Denklem 2.4).

$$
\mathrm{D}=\left[\begin{array}{cccc}
\mathrm{a}_{11} & \mathrm{a}_{12} & \cdots & \mathrm{a}_{1 \mathrm{n}} \\
\mathrm{a}_{21} & \mathrm{a}_{21} & \cdots & \mathrm{a}_{2 \mathrm{n}} \\
\cdot & \cdot & \cdot & \cdot \\
\cdot & \cdot & \cdot & \cdot \\
\cdot & \cdot & \cdot & \cdot \\
\mathrm{a}_{\mathrm{n} 1} & \mathrm{a}_{\mathrm{n} 2} & \cdots & \mathrm{a}_{\mathrm{nn}}
\end{array}\right] \times\left[\begin{array}{c}
\mathrm{w}_{1} \\
\mathrm{w}_{2} \\
\cdot \\
\cdot \\
\cdot \\
\mathrm{w}_{\mathrm{n}}
\end{array}\right]=\left[\begin{array}{c}
\mathrm{d}_{1} \\
\mathrm{~d}_{2} \\
\cdot \\
\cdot \\
\cdot \\
d_{\mathrm{n}}
\end{array}\right]
$$

d sütun vektörünün w sütun vektörünün karşılıklı elemanlarına bölünmesi ( $E_{\mathrm{i}}$ ) ile $\lambda$ değerine ulaşılır. $\lambda$ değerinin hesaplanmasında denklem 2.5 de belirtilen formüller kullanılır (Görçün, 2018).

$$
\mathrm{E}_{\mathrm{i}}=\frac{\mathrm{d}_{\mathrm{i}}}{\mathrm{w}_{\mathrm{i}}} \quad \lambda=\frac{\sum_{\mathrm{i}=1}^{\mathrm{n}} \mathrm{E}_{\mathrm{i}}}{\mathrm{n}}
$$

Uygulamamızdaki ana kriterler arası ikili karşılaştırma tutarlılık testi sonuçları Tablo 11'de verilmiştir.

Tablo 11. Tutarlılık Test Sonuçları (Consistency Results)

\begin{tabular}{|c|c|}
\hline D sütun vektörü & Ei \\
\hline 0,376867 & 3,003535 \\
\hline 1,609825 & 3,015096 \\
\hline 1,025287 & 3,010204 \\
\hline Lamda $(\lambda)$ & 3,009612 \\
\hline
\end{tabular}

$$
C I=\frac{\lambda-n}{n-1}=\frac{3,009612-3}{3-1}=0,004806
$$




$$
C R=\frac{C I}{R I}=\frac{0,004806}{1,24}=0,003876
$$

CR= 0,003876 değeri 0,1 değerinden küçük olduğu için tutarlı değerlendirme yapıldı̆̆ı anlaşılmıştır.

Yapılan ikili karşılaștırmalar ile elde edilen ana kriterlerin ağırlıkları (Tablo 6) sırasıyla 0,367, 0,206 ve 0,426 olarak belirlenmiştir. Ana kriterler içerisinde en fazla ağırlığa sahip kriter "toplanma alanı kapasitesi" dir. Onu 0,367 ile "ulaşılabilirlik" takip etmektedir. Alt kriter için ise (Tablo 8) 0,510 ile "yüksek yapılardan uzaklık" kriteri en yüksek öncelik vektörü değerine sahip kriter olarak görünmektedir. 1999 depremlerini yaşamış ve yapısal olarak büyük hasar almış olan Başiskele ilçesi için bu kriterin öncelikli olarak belirlenmesi oldukça normal bir sonuçtur. Çalıșma alanı için belirlenmiş 35 toplanma alanından 25 adedinin bu kritere uygun alanlardan belirlenmiş olması ise oldukça sevindirici bir durumdur. Özellikle deprem söz konusu olduğunda afet sonrası kullanılmak için belirlenmiş alanlar panik, korku ve karmaşa nedeniyle daha uzun süreli olarak kullanılmaktadır. İnsanların bu alanları kullanma süreleri uzadıkça temel ihtiyaçlar ve mevsime bağlı ihtiyaçlar önem kazanmaktadır. Bu nedenle belirlenen bu alanların uygun altyapı şartlarına sahip olması beklenen bir durumdur. $\mathrm{Bu}$ çalışma sonuçlarına göre altyapı kriterlerine bağlı öncelik vektörü değeri (Tablo 10) 0,533 ile "su" kriteridir. Onu 0,340 ile WC kriterleri takip etmektedir. Başiskele ilçesi için su altyapısına sahip 27 (\%77,14), WC altyapısına sahip $26(\% 74,29)$ toplanma alanı mevcuttur.

\section{Sonuç ve Tartışma (Result and Discussion)}

Olası büyük bir depremin hemen ardından evleri yıkılan, hasar gören veya korku ya da panik gibi sebeplere bağlı olarak evlerine giremeyen bireyler çoğu zaman afet anının sıcak saatlerde insanlarla bir arada bulunmayı tercih edecektir. Bir bölgeyi etkileyecek seviyede afetlere maruz kalındığı durumlarda ilgili kurumların afet risk yönetimi planlaması içerisinde daha önceden belirlemiş toplanma alanlarının bilinmesi ve kullanması gerekir. Ancak, bu alanların seçimi yerleșimin tamamlanmış olduğu bölgelerde çoğunlukla problem oluşturmaktadır.

Ülkemizde özellikle kentlerdeki yeşil alanlar konum ve büyüklük olarak çoğu zaman yetersiz kalmaktadır. Kocaeli gibi dağ-deniz mesafesinin dar olduğu kentlerde bu yetersizlik maalesef daha da ön plana çımaktadır. Kent yaşamının vazgeçilmez ihtiyaçlarından biri olan ve toplumun rekreasyona yönelik istek ve ihtiyaçlarını karşılayan bu yeşil alanlar afetler söz konusu olduğunda müdahale ve barınma ihtiyaçlarının karşılandığı alanlara dönüşmektedir. Açık yeşil alanların afet ve acil durumlar sonrası toplanma alanları olarak kullanıldığı düşünüldügünde bu alanların uluslararası standartlara sahip ve gerekli donatılar ile fonksiyonel hale getirilmesi toplumun afetlere direncini arttıran önemli unsurlardan bir tanesi olacaktır.

Bu çalışmada, Kocaeli AFAD İl Müdürlüğü tarafından Başiskele ilçesi için uluslararası standartlara uygun olarak belirlenmeye çalışılmış 35 adet toplanma alanının yeterlikleri değerlendirilmiş ve olası bir afet sonrası insanları bir araya getirerek temel ihtiyaçların karşılanmasını sağlayacak olan bu alanların kriterleri ile oluşturulan hiyerarşik yapının uygunluğu AHP yöntemi ile hesaplanarak önceliklendirilmiştir. Buna göre ana kriterler arasında en fazla ağırlığa sahip olan "Toplanma alanı kapasitesi” kriteridir. Çalıșmada değerlendirme alanı olarak seçilen Başiskele ilçesi toplanma alanlarının yeterlilik değerlendirmesi sonucunda;

$\checkmark$ Kişi başına düșen alan büyüklügü açısından toplanma alanlarının çoğunluğunun uygun olduğu görülmektedir. Toplam 22 mahallenin 17 adedi kişi başına $2 \mathrm{~m}^{2}$ nin üzerinde boş alana sahipken sadece 2 mahalle için $1 \mathrm{~m}^{2}$ nin altında uygunsuz alan görünmektedir. Bu mahalleler için alternatif toplanma alanlarının tespit edilmesi gerekmektedir.

$\checkmark$ Başiskele ilçesindeki toplanma alanlarının büyük bir çoğunluğu denize (f=32, \%91,43) ve yüksek yapılara uzak ( $\mathrm{f}=25, \% 71,43)$ olarak belirlenmiștir.

$\checkmark 35$ adet toplanma alanının $24(\% 68,57)$ adedi ana caddeye cephe iken $32(\% 91,43)$ adedi yaya yoluna sahip durumdadir.

Bu değerlendirmeler doğrultusunda, Başiskele ilçesi için belirlenmiş toplanma alanlarının uluslararası kriterlere oldukça uygun olarak belirlendiğini söylemek mümkündür. Ancak kentsel alanlara artan ilgi nedeniyle bu alanların zamanla azalacağı unutulmamalı ve yüksek binalara yakın toplanma alanları için yeni alternatifler üretilmelidir.

\section{Teşekkür (Acknowledgement)}

Kocaeli İl Afet ve Acil Durum Müdürlüğü Planlama ve Zarar Azaltma Şube Müdürlüğü çalışanlarına “toplanma alanı kriterlerinin ağırlıklandırılması" çalışmasına sağladıkları katkıdan dolayı teşekkür ederiz. 


\section{Çıkar Çatışması (Conflict of Interest)}

Yazarlar tarafından herhangi bir çıkar çatışması beyan edilmemiştir. No conflict of interest was declared by the authors.

\section{Kaynaklar (References)}

AFAD. 2019. Türkiye'de Afet Yönetimi ve Doğal Kaynaklı Afet İstatistikleri Raporu, Ankara.

Aksoy, Y., Turan, A.Y., Atalay, H., 2009. İstanbul Fatih ilçesi yeșil alan yeterliliğinin Marmara depremi öncesi ve sonrası değerleri kullanılarak incelenmesi. Uludağ Üniversitesi Mühendislik-Mimarlık Fakültesi Dergisi, 14(2), 137-150.

Aktaş, R., Doğanay, M. M. Gökmen, Y. Gazibey, Y. ve Türen, U., 2015. Sayısal Karar Verme Yöntemleri, İstanbul: Beta Yayınevi.

Akyürek, Ö., Arslan, O., 2018. Kocaeli İli ve Çevresinde (1900-2016) Yllları Arasında Gerçekleșen Tarihsel Depremlerin Konumsal İstatistik Analizi. Journal of Geomatics, 3(1); 48-62.

Birand, A. ve Ergünay, O., 2001. Türkiye'nin afet sorunlarına genel bakıș ve Erzincan depremi uygulaması. İstanbul: Türkiye Deprem Vakfi.

Cavuș, G., 2013. Deprem bölgelerindeki açılk yeșil alan sistemi ilke ve standartlarının Bolu ili örneğinde irdelenmesi. Yayımlanmamış doktora tezi. Ankara Üniversitesi Fen Bilimleri Enstitüsü, Ankara.

Çuvaş, N., 2002. İzmit Civarının Jeolojisi Ve Coğrafi Bilgi Sistemi. Yayımlanmamış yüksek lisans tezi. İstanbul Teknik Üniversitesi, Avrasya Yer Bilimleri Enstitüsü.

Çınar, A.K., Akgün, Y. ve Maral, H., 2018. Afet sonrası acil toplanma ve geçici barınma alanlarının planlanmasındaki faktörlerin incelenmesi: İzmir-Karşıyaka örneği. Planlama 28(2), 179-200 doi: 10.14744/planlama.2018.07088.

Çelik H.Z., Aydın, B.S., Partigöç, N.S., Erdin, H.E., 2018. Deprem riskleri bağlamında toplanma alanlarının güvenlik kriterleri temelinde değerlendirilmesi: Bayraklı (İzmir) örneği. 2nd. International Symposium on Natural Hazards and Disaster Management 04-06 May.

Çelikbilek Y., 2018. Çok Kriterli Karar Verme Yöntemleri, Nobel Yayınevi, 2018.

Çiçekdağı, H.i. ve Kırıș, Ş., 2012. Afet istasyonu ve toplanma merkezi için yer seçimi ve bir uygulama. Dumlupınar Üniversitesi, Fen Bilimleri Enstitüsü Dergisi, 28, 67-76.

Da Silva, J. ve Morera, B., 2014. City resilience framework. London: The Rockefeller Foundation.

Demirci, A. ve Karakuyu, M., 2014. Afet yönetiminde coğrafi bilgi teknolojilerinin rolü. Doğu Coğrafya Dergisi, 12, 67-100.

Erden T. ve Coşkun M. Z., 2010. Acil durum servislerinin yer seçimi: Analitik hiyerarşi yöntemi ve CBS entegrasyonu. İTÜ Dergisi, 9 (6), 37-50.

Erdin, E., Kama, S., Metin, T.C., 2017. Afet ve acil durumlarda iletişim, koordinasyon ve mekanlar; Acil durum bilgisi ve yönetimine giriș. Bölüm: 7, Editör: Çabuk, S. N., Çabuk, A., Eskișehir.

Erkan, M.A., Kılıç, G., Çamalan, G., Güser, Y., Çetin, S., Odabaşı, E., Soydam, M., Akgüngüz, A..S., Ayvacı, H., Eren, O., Arabacı, H., 2018. Meteorolojik karakterli doğal afetler 2017 yılı değerlendirmesi, Orman ve Su İșleri Bakanlığı, Meteoroloji Genel Müdürlüğ̈̈.

Gerdan, S. ve Șen A., 2019. Afet ve Acil Durumlar İçin Belirlenmiş Toplanma Alanlarının Yeterliklerinin Değerlendirilmesi: İzmit Örneği. İdealkent Dergisi. 10(28).

Görçün Ö.F., 2018. Kent İçi Ulașım Sistemlerine İlișkin Tercihlerin ve Tercihlere Etki Eden Faktörlerin Analitik Hiyerarși Prosesi Yöntemi İle Değerlendirilmesi, Kent Akademisi, 11 (33).

Gül, A. ve Küçük, V., 2001. Kentsel Açık-Yeşil Alanlar Ve Isparta Kenti Örneğinde İrdelenmesi. Süleyman Demirel Üniversitesi Orman Fakültesi Dergisi Seri: A, Sayı: 2.

Güvel, E.A., 2001. Doğal afetlerin politik ekonomisi. İstanbul: İstanbul Menkul Kiymetler Borsası Yayınları. 20-21,

Hazırcı, M., Şahin, Y., 2019. Geçici İskân Alanlarının Seçimi İçin Ahp Temelli P-Medyan Modeli: Burdur Örneği. Mühendislik Bilimleri ve Tasarım Dergisi, 7(2), 403 - 417.

JICA Japon Uluslararası İşbirliği Ajansı. 2002. Türkiye Cumhuriyeti İstanbul ili sismik mikro-bölgeleme dahil afet önleme/azaltma temel planı çalışması. İstanbul: Japon Uluslararası İşbirliği Ajansı ( JICA) ve İstanbul Büyükșehir Belediyesi (IBB).

Kadıoğlu, M., 2008. Modern, Bütünleșik Afet Yönetimin Temel İlkeleri; Kadıŏlu, M. ve Özdamar, E., (editörler), “Afet Zararlarını Azaltmanın Temel İlkeleri"; s. 1-34, JICA Türkiye Ofisi Yayınları No: 2, Ankara.

Kırçın, P.N., Çabuk, S.N., Aksoy, K., Çabuk, A., 2017. Ülkemizde yeșil alanların afet sonrası toplanma alanı olarak kullanılma olanaklarının artırılması üzerine bir araștırma, 4. Uluslararası Deprem Mühendisliği ve Sismoloji Konferansı, 11-13 Ekim.

Maral, H., Akgün, Y., Çınar, A.K. ve Karaveli, A.S., 2015. İzmir'deki afet sonrası toplanma ve acil barınma alanları üzerine bir değerlendirme, 3. Türkiye Deprem Mühendisliği ve Sismoloji Konferansı, 14-16 Ekim.

Press, F. ve Hamilton, M.,R., 1999. Mitigating natural disasters, Science, 284 (5422), 1927.

Saaty, T.L., 1980. The Analytic Hierarchy Process: Planning, Priority Setting, Resource Allocation

Saaty, T.L., 1990. How to make a decision: the analytic hierarchy process. European Journal of Operational Research, 48(1), 926.

Saaty, T.L., 1994. How to make a decision: the analytic hierarchy process. Interfaces, 24(6), 19-43.

Şahin, Y., Akyer, H., 2011. Ülke Kaynaklarının Verimli Kullanımı: 4x4 Arama ve Kurtarma Aracı Seçiminde AHS ve TOPSIS Yöntemlerinin Uygulaması. Vizyoner Dergisi, 3(5), 72-87.

Tarabanis, K. ve Tsionas, I., 1999. Using network analysis for emergency planning in case of earthquake. Transactions in GIS, $3(2), 187-197$.

Yalçıner Çal, D., Aydemir, E., 2018. Yerleşke içi acil durum toplanma yerlerinin belirlenmesi: Süleyman Demirel Üniversitesi örneği. Mühendislik Bilimleri ve Tasarım Dergisi, 6(3).

Yıldırım, B. F. ve Önder, E., 2018. Cok Kriterli Karar Verme Yöntemleri, İstanbul: Dora Yayınevi. 
URL-1. Evac Services Web. , Assembly Area Requirements You Should Know, 01 Kasım 2018 tarihinde https://www.evacservices.com.au/assembly-area-requirements/ adresinden erişildi.

URL-2. City Fire Protection Web, Evacuation Procedures: Choosing your Assembly

Point, https://www.cityfire.co.uk /news/evacuation-procedures -choosing-your-assembly-point/ adresinden erișildi.

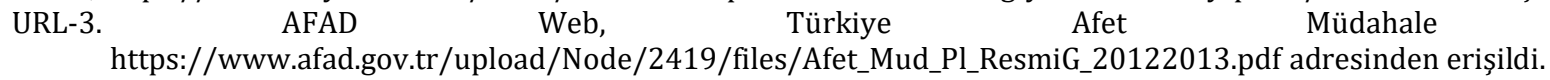
URL-4
Resmi
Gazete
Web,
E-Mevzuat, https://www.mevzuat.gov.tr/Metin.Aspx?MevzuatKod=7.5.19788\&MevzuatIliski=0\&sourceXmlSearch=mekan adresinden erișildi.

URL-5. Kocaeli AFAD Web, Kocaeli İl Afet Müdahale Planı https://kocaeli.afad.gov.tr/upload/Node/17079/files/TAMPKOCAELI_AFET_MUDAHALE_PLANI.pdf adresinden erişildi

URL- 6. Kocaeli Büyükșehir Belediyesi- Bașiskele İlçe Bilgileri https://www.kocaeli.bel.tr/tr/main/pages/basiskele-ilcesi/203 adresinden erişildi. 
EK-1. Başiskele İlçesi Toplanma Alanları Altyapı Bilgileri (AFAD, 2019) (Infrastructure Information for Assembly Points of Basiskele District (AFAD, 2019))

\begin{tabular}{|c|c|c|c|c|c|c|c|c|c|c|c|c|c|c|c|}
\hline $\begin{array}{l}\text { Alan } \\
\text { No }\end{array}$ & Alan Adı & Mahalle & Cadde/Sokak & $\begin{array}{l}\text { Ana } \\
\text { Caddeye } \\
\text { Cephe }\end{array}$ & $\begin{array}{l}\text { Denize } \\
\text { Uzaklk } \\
(>200 \mathrm{~m}) \\
\end{array}$ & $\begin{array}{l}\text { Yüksek } \\
\text { Yapılardan } \\
\text { Uzaklık } \\
(>30 \mathrm{~m}) \\
\end{array}$ & $\begin{array}{l}\text { Yaya } \\
\text { Yolu }\end{array}$ & $\begin{array}{l}\text { Engelli } \\
\text { Yolu }\end{array}$ & Elektrik & Su & wC & $\begin{array}{l}\text { Alan } \\
\left(m^{2}\right)\end{array}$ & Kapasite & Nüfus & $\begin{array}{l}\text { Kişi } \\
\text { Başi } \\
\text { Alan } \\
\left(>2,5 \mathrm{~m}^{2}\right) \\
\end{array}$ \\
\hline 1 & $\begin{array}{l}\text { MİSAKI } \\
\text { MİLLİIÖO.VE } \\
\text { SAĞLIK TESISİ } \\
\text { ALANI } \\
\end{array}$ & $\begin{array}{l}\text { ALTINKEN } \\
\text { T MAH. }\end{array}$ & 29 EKіМ CAD. & Var & Evet & Evet & Var & Var & Var & Var & Var & 10.000 & 25.000 & 2680 & 3,73 \\
\hline 2 & $\begin{array}{l}\text { DENIZDiBII İLK VE } \\
\text { ORTAOKULU }\end{array}$ & $\begin{array}{l}\text { ATAKENT } \\
\text { MAH. }\end{array}$ & $\begin{array}{l}\text { ZÜBEYDE } \\
\text { HANIM CAD. }\end{array}$ & Var & Evet & Evet & Var & Var & Var & Var & Var & 8.000 & 20.000 & 3787 & 2,11 \\
\hline 3 & $\begin{array}{l}\text { RECEP KARAASLAN } \\
\text { PARKI }\end{array}$ & $\begin{array}{l}\text { AYDINKEN } \\
\text { T MAH. }\end{array}$ & $\begin{array}{l}\text { EŞREF BITLIS } \\
\text { CAD. }\end{array}$ & Var & Evet & Evet & Var & Var & Var & Var & Yok & 7.000 & 17.500 & 2580 & 2,71 \\
\hline 4 & $\begin{array}{l}\text { BARBAROS İLK VE } \\
\text { ORTAOKULU }\end{array}$ & \multirow[b]{2}{*}{$\begin{array}{l}\text { BARBAROS } \\
\text { MAH. }\end{array}$} & $\begin{array}{l}\text { TURGUT ÖZAL } \\
\text { CAD. }\end{array}$ & Yok & Evet & Evet & Var & Var & Var & Var & Var & \multirow[b]{2}{*}{24.730} & \multirow[b]{2}{*}{61.825} & \multirow[b]{2}{*}{9737} & \multirow[b]{2}{*}{2,54} \\
\hline 5 & $\begin{array}{l}\text { KARŞIYAKA ( SPOR } \\
\text { TESISI ALANI ) }\end{array}$ & & $\begin{array}{l}\text { YUNUS EMRE } \\
\text { CAD.- } \\
\text { BEYAZIT CAD. }\end{array}$ & Yok & Evet & Evet & Var & Var & Var & Var & Var & & & & \\
\hline $\begin{array}{l}6 \\
7\end{array}$ & $\begin{array}{l}\text { BAHÇECIK DAMLAR } \\
\text { ILLKOKULU } \\
\text { PARK ALANI }\end{array}$ & $\begin{array}{l}\text { DAMLAR } \\
\text { MAH. }\end{array}$ & $\begin{array}{l}\text { MAHMUT } \\
\text { ÇAVUŞ CAD. } \\
\text { HACI ASLAN } \\
\text { CAD. }\end{array}$ & $\begin{array}{l}\text { Var } \\
\text { Var }\end{array}$ & $\begin{array}{l}\text { Evet } \\
\text { Evet }\end{array}$ & $\begin{array}{l}\text { Evet } \\
\text { Evet }\end{array}$ & $\begin{array}{l}\text { Var } \\
\text { Var }\end{array}$ & $\begin{array}{l}\text { Var } \\
\text { Var }\end{array}$ & $\begin{array}{l}\text { Var } \\
\text { Var }\end{array}$ & $\begin{array}{l}\text { Var } \\
\text { Var }\end{array}$ & $\begin{array}{l}\text { Var } \\
\text { Var }\end{array}$ & 8.000 & 20.000 & 2269 & 3,53 \\
\hline 8 & $\begin{array}{l}\text { KARSYIYAKA AÇIK } \\
\text { MEYDAN ALANI }\end{array}$ & $\begin{array}{l}\text { DÖNGEL } \\
\text { MAH. }\end{array}$ & $\begin{array}{l}\text { DÜZLEM- } \\
\text { SAĞDIÇ } \\
\text { SOKAK } \\
\end{array}$ & Yok & Evet & Evet & Var & Yok & Yok & Yok & Yok & 2.775 & 6.938 & 2047 & 1,36 \\
\hline 9 & $\begin{array}{l}\text { YUVACIK İLK VE } \\
\text { ORTAOKULU }\end{array}$ & $\begin{array}{l}\text { FATIH } \\
\text { MAH. }\end{array}$ & $\begin{array}{l}\text { BAHTIYAR } \\
\text { SOK. }\end{array}$ & Var & Evet & Hayır & Var & Var & Var & Var & Var & 1.500 & 3.750 & 6009 & 0,25 \\
\hline 10 & $\begin{array}{l}\text { KULLAR } \\
\text { VEZIRCCífTLLiĞí } \\
\text { O.O.V.İHSAN DEDE } \\
\text { İÖO. } \\
\text { KULLAR ( } \\
\text { DÜZENLENMEMiş } \\
\text { PARK ALANI) } \\
\end{array}$ & $\begin{array}{l}\text { KARADENİ } \\
\text { ZLİLER } \\
\text { MAH. }\end{array}$ & YONCALI SOK. & Yok & Evet & Hayır & Var & Var & Yok & Var & Var & 13.282 & 33.205 & 2428 & 5,47 \\
\hline $\begin{array}{l}12 \\
13 \\
\end{array}$ & $\begin{array}{l}\text { BAHÇECIK (SPOR } \\
\text { TESISI ALANI) } \\
\text { CUMHURIYET } \\
\text { PARKI } \\
\end{array}$ & $\begin{array}{l}\text { KILIÇARSL } \\
\text { AN MAH. }\end{array}$ & $\begin{array}{l}\text { DÜZLÜK CAD. } \\
\text { ZEYNEP } \\
\text { ULTAVSK. }\end{array}$ & $\begin{array}{l}\text { Var } \\
\text { Var }\end{array}$ & $\begin{array}{l}\text { Evet } \\
\text { Evet }\end{array}$ & $\begin{array}{l}\text { Evet } \\
\text { Evet }\end{array}$ & $\begin{array}{l}\text { Var } \\
\text { Var }\end{array}$ & $\begin{array}{l}\text { Var } \\
\text { Var }\end{array}$ & $\begin{array}{l}\text { Var } \\
\text { Var }\end{array}$ & $\begin{array}{l}\text { Var } \\
\text { Var }\end{array}$ & $\begin{array}{l}\text { Var } \\
\text { Var }\end{array}$ & 14352 & 35880 & 2641 & 5,43 \\
\hline 14 & $\begin{array}{l}\text { KÖRFEZ İLK VE } \\
\text { ORTAOKULU }\end{array}$ & $\begin{array}{l}\text { KÖRFEZ } \\
\text { MAH. }\end{array}$ & $\begin{array}{l}\text { D-130 } \\
\text { KARAYOLU } \\
\text { CAD. } \\
\end{array}$ & Var & Evet & Evet & Var & Var & Var & Var & Var & 2.000 & 5.000 & 2745 & 0,73 \\
\hline 15 & $\begin{array}{l}\text { KARTONSAN İLK VE } \\
\text { ORTAOKULU }\end{array}$ & $\begin{array}{l}\text { KULLAR } \\
\text { YAKACIK } \\
\text { MAH. }\end{array}$ & ÖZEN SOK. & Yok & Evet & Hayır & Var & Var & Var & Var & Var & 3.500 & 8.750 & 1705 & 2,05 \\
\hline 16 & PARK ALANI & $\begin{array}{l}\text { MEHMETA } \\
\text { ĞA MAH. }\end{array}$ & $\begin{array}{l}\text { KARAMÜRSEL } \\
\text { CAD. }\end{array}$ & Var & Evet & Evet & Var & Var & Var & Var & Var & 4.000 & 10.000 & 1398 & 2,86 \\
\hline 17 & $\begin{array}{l}\text { KULLAR ( ACCIK } \\
\text { SPOR TESISII ALANI ) }\end{array}$ & $\begin{array}{l}\text { OVACIK } \\
\text { MAH. }\end{array}$ & $\begin{array}{l}\text { YENİ YOL } \\
\text { CADDESI } \\
\end{array}$ & Yok & Evet & Evet & Var & Var & Var & Var & Var & 29.000 & 72.500 & 1160 & 25,00 \\
\hline $\begin{array}{l}18 \\
19 \\
\end{array}$ & $\begin{array}{l}\text { KOÜ DİS HEKIMMLİĞİ } \\
\text { FAKÜLTESI } \\
\text { YUVACIK ( SPOR } \\
\text { TESİİ ALANI ) }\end{array}$ & $\begin{array}{l}\text { PAŞADAĞ } \\
\text { MAH. }\end{array}$ & $\begin{array}{l}\text { SAĞLIK SOK. } \\
\text { NURİ PAŞA } \\
\text { CAD. }\end{array}$ & $\begin{array}{l}\text { Var } \\
\text { Var }\end{array}$ & $\begin{array}{l}\text { Evet } \\
\text { Evet }\end{array}$ & $\begin{array}{l}\text { Evet } \\
\text { Evet }\end{array}$ & $\begin{array}{l}\text { Var } \\
\text { Var }\end{array}$ & $\begin{array}{l}\text { Var } \\
\text { Var }\end{array}$ & $\begin{array}{l}\text { Var } \\
\text { Var }\end{array}$ & $\begin{array}{l}\text { Var } \\
\text { Var }\end{array}$ & $\begin{array}{l}\text { Var } \\
\text { Var }\end{array}$ & 64.409 & 161.023 & 3391 & 18,99 \\
\hline $\begin{array}{l}20 \\
21\end{array}$ & $\begin{array}{l}\text { YENIKÖY ( BOŞ } \\
\text { PARK ALANI) } \\
\text { SEPETLIPINAR ILK } \\
\text { VE ORTAOKULU } \\
\end{array}$ & $\begin{array}{l}\text { SEPETLIPI } \\
\text { NAR MAH. }\end{array}$ & $\begin{array}{l}\text { ZÜMRÜT } \\
\text { SOKAK } \\
\text { EGEMEN CAD. }\end{array}$ & $\begin{array}{l}\text { Yok } \\
\text { Yok }\end{array}$ & $\begin{array}{l}\text { Hayır } \\
\text { Hayır }\end{array}$ & $\begin{array}{l}\text { Evet } \\
\text { Hayır }\end{array}$ & $\begin{array}{l}\text { Var } \\
\text { Var }\end{array}$ & $\begin{array}{l}\text { Yok } \\
\text { Var }\end{array}$ & $\begin{array}{l}\text { Yok } \\
\text { Var }\end{array}$ & $\begin{array}{l}\text { Yok } \\
\text { Var }\end{array}$ & $\begin{array}{l}\text { Yok } \\
\text { Var }\end{array}$ & 4.500 & 11.250 & 1297 & 3,47 \\
\hline 23 & $\begin{array}{l}\text { YUVACIK SERDAR } \\
\text { İLKOKULU } \\
\text { ORTAÖĞRETIM - } \\
\text { KÜLTÜREL TEISİ } \\
\text { ALANI ( BOȘ ) }\end{array}$ & $\begin{array}{l}\text { SERDAR } \\
\text { MAH. }\end{array}$ & $\begin{array}{l}\text { S.GAFFAR } \\
\text { OKKAN CAD. } \\
\text { EMIR SULTAN } \\
\text { CAD. - ISMAIL } \\
\text { GAZI SOK. } \\
\end{array}$ & Var & Evet & Hayır & Var & Var & Yok & $\begin{array}{l}\text { Var } \\
\text { Yok }\end{array}$ & Yok & 17.390 & 43.475 & 7098 & 2,45 \\
\hline 24 & $\begin{array}{l}\text { SEYMEN 8.BORU } \\
\text { ILLKOKULU }\end{array}$ & & $\begin{array}{l}\text { D-130 } \\
\text { KARAYOLU } \\
\text { CAD. }\end{array}$ & Var & Evet & Hayır & Var & Var & Var & Var & Var & & & & \\
\hline 26 & $\begin{array}{l}\text { BAHÇECIK ( } \\
\text { DÜZENLENMIŞ } \\
\text { PARK ALANI) } \\
\text { BAHÇECIK MES.VE } \\
\text { TEK.AND.LiSESI }\end{array}$ & $\begin{array}{l}\text { SEYMEN } \\
\text { MAH. }\end{array}$ & $\begin{array}{l}\text { GÜNAYDIN } \\
\text { CAD. } \\
\text { GÜLBAHAR } \\
\text { HATUN CD. }\end{array}$ & Var & Evet & Hayır & Var & Var & Var & Var & Var & 10.983 & 27.458 & 4056 & 2,71 \\
\hline 27 & PARK ALANI & $\begin{array}{l}\text { YAYLACIK } \\
\text { MAH. }\end{array}$ & $\begin{array}{l}\text { KARAMÜRSEL } \\
\text { CAD. }\end{array}$ & Var & Evet & Evet & Var & Yok & Yok & Yok & Yok & 46.500 & 116.250 & 2465 & 18,86 \\
\hline 28 & $\begin{array}{l}\text { KULLAR ( } \\
\text { DÜZENLENMEMIŞ } \\
\text { PARK ALANI) }\end{array}$ & & TALIM SOK. & Yok & Hayır & Hayır & Yok & Yok & Yok & Yok & Yok & & & & \\
\hline 29 & $\begin{array}{l}\text { YENIKÖY MERKEZ } \\
\text { PARKI }\end{array}$ & YENIKÖY & CEVIZLIK CAD. & Var & Evet & Evet & Var & Var & Var & Var & Var & & & & \\
\hline 30 & $\begin{array}{l}\text { YENIKÖY } \\
\text { MERKEZ(KÜLTÜREL } \\
\text { TESIS ALANI) }\end{array}$ & $\begin{array}{l}\text { MERKEZ } \\
\text { MAH. }\end{array}$ & VATAN CAD. & Var & Evet & Evet & Var & Var & Var & Var & Var & 13.590 & 33.975 & 5010 & 2,71 \\
\hline 31 & $\begin{array}{l}\text { YESSİLKENT İLK VE } \\
\text { ORTAOKULU }\end{array}$ & $\begin{array}{l}\text { YEŞiLKENT } \\
\text { MAH. }\end{array}$ & $\begin{array}{l}\text { MANZARA } \\
\text { CAD. }\end{array}$ & Var & Evet & Hayır & Var & Var & Var & Var & Var & 4.800 & 12.000 & 3110 & 1,54 \\
\hline 32 & $\begin{array}{l}\text { YUVACIK (BOŞ } \\
\text { PARK ALANI) }\end{array}$ & & ARAS SOK. & Yok & Evet & Evet & Var & Yok & Yok & Yok & Yok & & & & \\
\hline 33 & $\begin{array}{l}\text { YUVACIK ( BOS } \\
\text { PARK ALANI) }\end{array}$ & $\begin{array}{l}\text { YEŞiLYURT } \\
\text { MAH. }\end{array}$ & $\begin{array}{l}\text { HAFIZ } \\
\text { BAYRAM SOK. } \\
-\quad \text { ER SOK. }\end{array}$ & Var & Evet & Hayır & Yok & Yok & Yok & Yok & Yok & 11.687 & 29.218 & 8776 & 1,33 \\
\hline 34 & $\begin{array}{l}\text { LEVENT KIRCA } \\
\text { IO.VE OYA BASSAR } \\
0.0 \\
\end{array}$ & & $\begin{array}{l}\text { LEVENT } \\
\text { KIRCA CAD. }\end{array}$ & Var & Evet & Evet & Var & Var & Var & Var & Var & & & & \\
\hline 35 & YAKACIK PARKI & $\begin{array}{l}\text { YUVACIK } \\
\text { YAKACIK } \\
\text { MAH. } \\
\end{array}$ & $\begin{array}{l}\text { HACI } \\
\text { MAHMUT } \\
\text { CAD. } \\
\end{array}$ & Var & Evet & Evet & Var & Var & Var & Var & Var & 12.712 & 31.780 & 1390 & 9,15 \\
\hline
\end{tabular}

